\title{
Pillule Dosage Unit
}

National Cancer Institute

\section{Source}

National Cancer Institute. Pillule Dosage Unit. NCI Thesaurus. Code C149757.

A unit of presentation used to represent the quantity of product that is found in a single discrete entity where the pharmaceutical dose form is a type of pillule. 